\title{
A Holistic Approach for Wind Farm Site Selection by FAHP
}

\author{
Ilhan Talinli' ${ }^{1}$ Emel Topuz ${ }^{1}$, Egemen Aydin ${ }^{1}$ and Sibel B. Kabakc1 ${ }^{2}$ \\ ${ }^{1}$ Istanbul Technical University, Environmental Engineering Department \\ ${ }^{2}$ Yalova University, Energy Systems Engineering Department
}

Turkey

\section{Introduction}

In recent years an increasing number of countries have implemented policy measures to promote renewable energy. However, the most important problem that the policy makers face with is the conflicting linguistic terms and subjective opinions on energy and environment policy. As the environmental policy and energy policy always go hand in hand, it is quite clear that wind as a renewable resource should be competitive with conventional power generation sources. From technical, environmental, socio-economical and socio-political standpoint, wind power is the most deserving of all of the cleaner energy production options (geothermal, solar, tidal, biomass, hydro) for more widespread deployment. Although wind power is a never ending green resource, assessment of environmental risks and impacts- which comprise the backbone of environmental policy- in the context of specific projects or sites often are necessary to explicate and weigh the environmental trade-offs that are involved. In the case of wind farms, a number of turbines (ranging from about $250 \mathrm{~kW}$ to $750 \mathrm{~kW}$ ) are connected together to generate large amounts of power. Apart from the constraints resulting from the number of turbines, any site selection should think over the technical, economic, social, environmental and political aspects. Each aspect uses criteria for its own evaluation. Decision making by using multi criteria decision analysis is an attractive solution for obtaining an integrated decision making result. Although Lee et al. (2009), Kaya and Kahraman (2010) and Tegou et al. (2010) has studied wind farm site selection by using different kinds of Analytic Hierarchy Process (AHP), Cheng's extent analysis of Fuzzy AHP (FAHP) is used in this study and a holistic hierarchy were developed.

The analytic hierarchy process (AHP) is a multi-criteria decision making tool to deal with complex, unstructured and multi-attribute problems. This method is distinguished from other multi-criteria methods in three ways: I. Construction of the hierarchy structure II. Pairwise comparisons of different criteria III. Weighing with respective to the overall objective. In AHP, decision makers quantify the importance of criteria by using Cheng's 1-9 scale. To overcome the disadvantage of reluctant and inconsistent comparison judgments, fuzzy analytic hierarchy process (FAHP) might be used on each factor to determine the weight of fuzziness of its attributes. Hierarchy structure diagram of wind farm site selection is given in Figure 1. This study aims to apply the FAHP to find priority sequence of alternatives and obtain the key success factors for the selection of appropriate sites of wind farms. 
Technical factors are related with the suitability of site for wind energy production. An average wind speed must be sustained in the area in order to product wind energy. Land topography and geology must ensure some specifications for tribune construction. Tribune size is also a distinguishing factor, because it changes region to region due to some regional differences. Additionally, wind farm sitting depends on existing grid structure and connection conditions for transmission process. Capital costs such as construction, equipment e.g., land and operational \& management costs change from site to site based on site specifications. Electricity market in the region will affect the capacity of the farm directly. Incentives provided by some regional governance can determine the attractiveness of the site for wind farm due to economic reasons. When the wind energy production process evaluated in a systematic manner, it is seen that possible environmental impacts are related with noise, aesthetic, wild life and endangered species near wind farm site and electromagnetic interference. Socio-political aspects consist of regulating barriers, public acceptance, land use in the area and distance from residential area. Regulatory actions differ for regions and set some restrictions or incentives related with the sitting wind farms such as limitations for distance from grid or land use in the area. As a party of wind farm projects, public may oppose wind farm sitting due to some regional specifications such as environmental aspects. Alternative and especially existing land use options in the region might reduce or increase the suitability of wind farm sitting such as being a touristic or strategic region. More factors could be added to or some factors could be eliminated from hierarchy based on the need of analysis or characteristics of the sites that are being evaluated.

In conclusion, although wind is one of the renewable energy sources and have begun to be preferred commonly; wind farm sitting must be evaluated with a holistic approach by considering all of the aspects such as technical, economic, environmental and socio-political in order to integrate energy policy with environmental policy for sustainable environment.

\section{Wind farm}

In recent years, many people have recognized the value of wind power as a major renewable energy source of long term; because wind is free, clean and renewable. Thus, using wind power helps to reduce the dependence on traditional fossil fuel based power generation. This in turn ensures the environmental sustainability and security of supply. Furthermore, wind energy is reported to be close to become financially self-sustaining without the extensive governmental support (Welch and Venkateswaran, 2009).

Wind energy can be harnessed by a single wind turbine or several power generating units which are commonly called as wind farm. A wind farm has the following components:

- $\quad$ wind turbines

- towers

- transformers

- internal access roads

- transformer station

- transmission system connecting the facility to the national grid (UNDP, 2010).

The blades of the turbine collect the kinetic energy of the wind. Flow of the wind over the blade causes lift which results a rotation. The blades are connected to a drive shaft that turns an electric generator through a gear box. The profitability of generating wind energy mainly depends on the site of the wind farm. An inadequate site selection would lead to lower than 


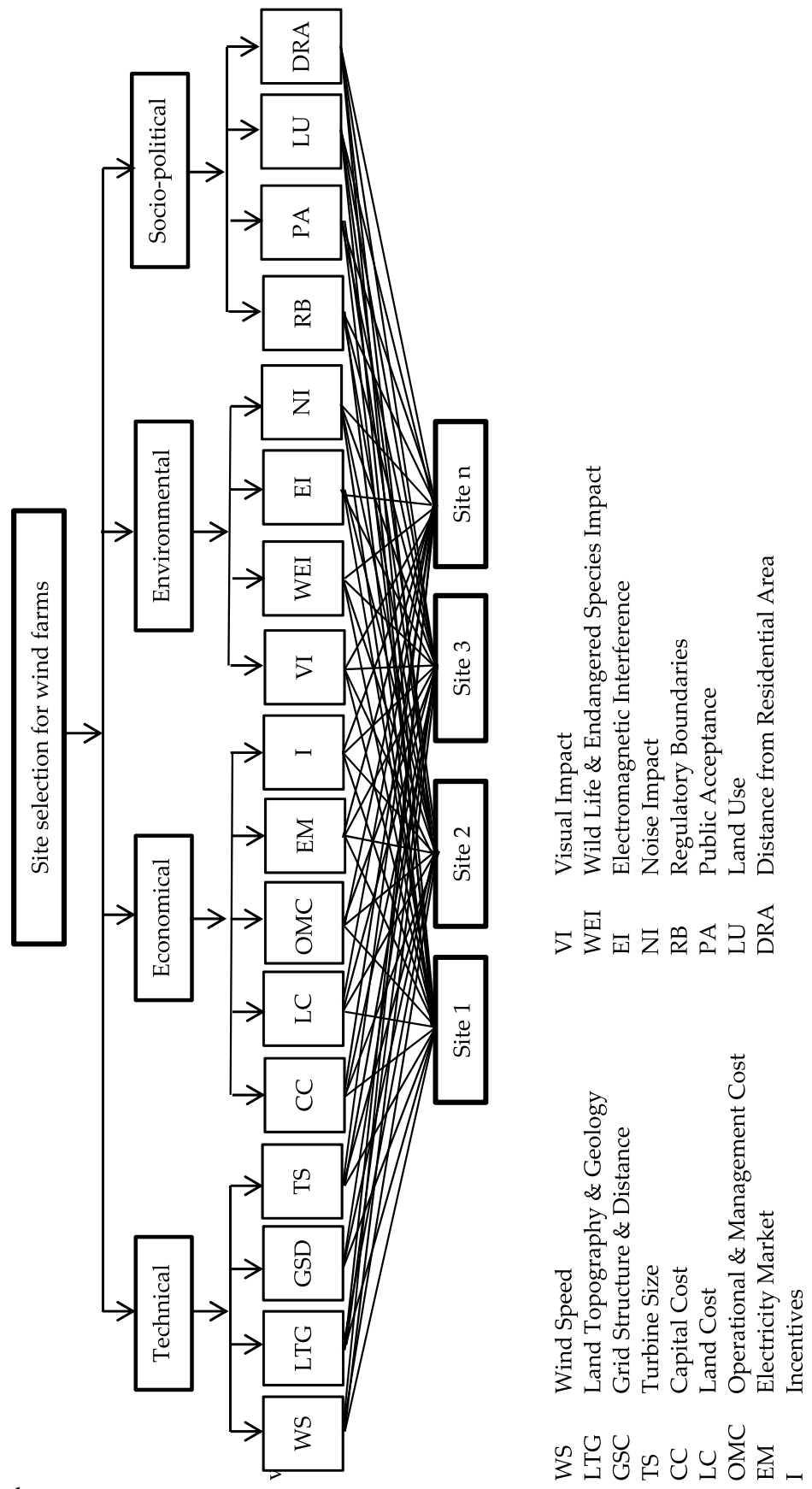

* Priority Number

Fig. 1. Hierarchy structure diagram for wind farm site selection 
expected wind power capture, increased maintenance costs, and so on (Kusiak and Song, 2010). Finding a wind farm site is so critical that the site is required to maximize the energy production and minimize the capital cost (EWEA, 2009). The decision of which areas to consider for siting wind farms and where to place wind turbines is a complex study involving not only technical considerations, but also economic, social and environmental requirements (Tegou et al., 2010). This complexity is resulting because of the combination of obstacles in siting process including environmental, topographic and geographic constraints, public opposition, regulatory barriers etc.

\subsection{Technical considerations}

Many technical factors affect the decision making on site selection including wind speed, land topography and geology, grid structure and distance and turbine size. These technical factors must be understood in order to give pair-wise scores to sub-factors.

\subsubsection{Wind speed}

The viability of wind power in a given site depends on having sufficient wind speed available at the height at which the turbine is to be installed (Vanek and Albright, 2008). Any choice of wind turbine design must be based on the average wind velocity at the selected wind turbine construction site (Ucar and Balo, 2009). In most of the countries, meteorological stations may provide average wind velocity data and wind maps for the regions. Cubic wind speed directly related with the energy generation potential of wind. Site's wind energy potential can be formulated with the wind power density which represents the effect of wind speed distribution and wind speed. Wind speed data must be recorded for at least 1 year in order to have mapping for potential energy yield over site. WindPro, WAsP, MesoMap are most widely used wind source mesoscale mapping software that use a variety of parameters in order to combine weather and wind flow models (Ozerdem et al., 2006).

\subsubsection{Land topography and geology}

The speed and the direction of wind can be various depending on the characteristics of topography (Brower, 1992). Wind farms typically need large lands. Topography and prevailing wind conditions determine turbine placement and spacing within a wind farm. In flat areas where there is nothing to interfere with wind flow, at least 2600-6000 $\mathrm{m}^{2} / \mathrm{MW}$ may be required (Kikuchi, 2008). More land may be needed in areas with more rugged or complex topography and/or wind flow interference. Wind turbines are usually sited on farms that have slope smaller than 10-20\% (Baban and Parry, 2001). Garrique or maquis are more advantageous than forests as land cover for wind farm sitting (Tegou et al., 2010). It would be needed to clear and grade land in order to provide roads for trucks, constructions trailer or equipment storage area, access to construction site. Soil stability, foundation requirements, drainage and erosion problems must be assess by conducting geotechnical study (Ozerdem et al., 2006).

\subsubsection{Grid structure and distance}

The connection of wind turbines to an electricity grid can potentially affect reliability of supply and power quality, due to the unpredictable fluctuations in wind power output (Weisser and Garcia, 2005). Feeding intermittent power into electricity grids can affect 
power quality. The impact depends primarily on the degree to which the intermittent source contributes to instantaneous load (i.e. on power penetration). At low penetrations, wind farms can be connected to the grid as active power generators, with control tasks concentrated at conventional plants. Many studies agree that penetrations of up to $10-20 \%$ can be absorbed in electricity networks without adversely affecting power quality and needing extra reserve capacity (Weisser and Garcia, 2005). Grid distance is one of the 10 most important steps that were determined by American Wind Energy Association (AWEA) for wind farm building (AWEA, 2007).

\subsubsection{Turbine size}

Required height for the installation of turbine above ground is one of the important factors that affect the annual energy generation (Herbert et al., 2007). Turbine size is related with the energy output, because the bigger the turbine size is, the more wind it is exposed to. However, bigger turbines need bigger turbine towers which can be limited with construction and maintenance related with site dependent specifications (Munday et al., 2011).

\subsection{Economic considerations}

The economic sub factors that affect the site selection include capital cost, land cost and operational and management costs. One of the biggest advantages of renewable energy sources is that there is no fuel cost during operation of the plant, therefore contribution of capital cost to the overall wind farm economy is very high. It is important to make economical evaluations by considering time value of money due to long periods of service life of wind farm projects (Ozerdem et al., 2006).

\subsubsection{Capital cost}

Construction, electrical connection, grid connection, planning, wind turbines, approvals, utilities and management are the main components of capital cost for wind farm projects (Lee et al., 2009). There will be meteorological towers which will include anemometers to measure wind speed and direction, a data logger and meteorological mast. Steel tube or lattice could be used to construct these towers and would be free standing or guyed. It is required to take a special permit in order to build such a meteorological tower (AWEA, 2007). Capital cost related with these components will change due to region that wind farm is located. It would be needed to clear about 150-250 feet around a wind turbine site to prepare wind turbine construction. Electrical collection lines are constructed in order to connect wind turbines and collection substation. Based on the land geometry, costs of these lines vary. Even, O\&M building would need new roadways, sewage collection system to main collector or installation of municipal water connection. In addition, construction debris is also one of the expenses that must be considered.

Capital cost of a typical wind farm project change between $£ 600,000$ and $£ 1,000,000$ per MW per annum. Turbine costs $(64 \%)$, construction (13\%) and electrical infrastructure (8\%) costs constitute the major items of capital expenditures (Munday et al., 2011). The amount of transmission infrastructure that has to be installed directly increases the cost of building a wind farm. Therefore, availability of existing transmission lines should be considered in selecting a site. 


\subsubsection{Land cost}

Generally, wind power production cost is currently higher than that of the conventional fuels. Technology of the production is the main effect of cost in the case of production cost. But for the site selection, main economic factor is the cost of the land where the wind farm is constructed; because, the cost of land primarily depends on the region, soil condition and the distance from the residential area. Since large areas are needed for wind farms, the rent or cost of the land becomes the major factor of site selection. For a commercially viable project, the size of the site is a crucial parameter. As the size of the site gets bigger, the possibility of facing with more than one landowner increases. The ideal situation is to communicate with few landowners who can give exclusive rights to the wind power project owner.

\subsubsection{Operational and management cost}

There will be control functions such as supervisory control and data acquisition (SCADA) which will provide control of each wind turbine in O\&M facilities. It is estimated that O\&M cost of wind farms require about $£ 8000-£ 10,000$ per MW per annum. Business rates, maintenance expenses, rents, staff payments are main components of O\&M costs. O\&M cost are usually very small percentage of total investment costs of wind farm projects (Munday et al., 2011).

\subsubsection{Electricity market}

Existing of an electricity market for the energy generated is an important factor affecting the economic benefits of the project. There should be energy demand in regions close to wind farms. When the intermittency of the wind energy taken into consideration, a continuous electricity market gains an extra importance for the region wind farm sited.

\subsubsection{Incentives}

Incentives are economic tools applied in order to encourage investors to support socially beneficial projects such as renewable energy projects that reduce the number of thermal power plants and so the carbon emissions. Regions, where advantageous incentives applied for wind energy generators, are very fascinating for the economic considerations.

Applications of incentives such as specific levy exemptions and renewables obligations certificates vary from region to region (Munday et al., 2011). For example, China has been applying some concession programs for wind power generation since 2005 (Zhang, 2007). In Turkey, in the Law on The Utilization of Renewable Energy Resources For The Purpose of Generating Electrical Energy, there is a special case for the investors in the cost of land. In the case of utilization of property which is under the possession of Forestry or Treasury or under the sovereignty of the State for the purpose of generating electricity from the renewable energy resources included in the law, these territories are permitted on the basis of its sale price, rented, given right of access, or usage permission by the Ministry of Environment and Forestry or the Ministry of Finance (Erdoğdu, 2009). A 50\% deduction shall be implemented for permission, rent, right of access, and usage permission in the investment period.

\subsection{Environmental considerations}

The environmental sub factors that affect the site selection of a wind farm include visual impact, electromagnetic interference, wild life and endangered species and noise impact. As 
a renewable energy source, wind farm do not cause reduction in natural resources. As a result of having no input other than wind, there is no formation of emission during the energy generation process. Wind turbines can generate noise while they are working and their image can be incompatible with the general view of the region. Wild life and endangered species could be disturbed during the construction of wind farm.

\subsubsection{Visual impact}

Wind turbines are located in windy places, and most of the time, those places are highly visible. To many people, those big towers with 2 or 3 blades create visual pollution. To minimize the impacts of visual pollution, many investors implement the actions listed below:

- The wind turbine tower, nacelle and blades as well as the transformer box, is painted a neutral color to blend in with the surroundings.

- The turbine is sited to reduce the possibility of shadow flicker falling on surrounding inhabited structures.

\subsubsection{Wild life \& endangered species}

Wind farms affect birds mainly through the actions listed below:

- collision with turbines and associated power lines,

- disturbance leading to displacement including barriers to movement,

- $\quad$ loss of habitat resulting from wind turbines (Bright et al., 2008; Kikuchi, 2008).

To minimise the risk of bird collision, site selection should be done precisely. But decision making in site selection is problematic due to the reason that migration roads of birds may vary from one year to another. Long term monitoring before giving the decision is necessary. Also, soil and water habitat must be protected from possible effects of wind farm projects (AWEA, 2007).

\subsubsection{Electromagnetic interference}

Electromagnetic interference is an electromagnetic disturbance that interrupts, obstructs, or degrades the effective performance of electronics or electrical equipment (Manwell et al., 2002). Wind turbines may reflect, scatter or diffract the electromagnetic waves which in turn interfere with the original signal arriving at the receiver. Although several parameters that influence the extent of electromagnetic interference are listed in the study of Manvell et al. (2002) the blade construction material and rotational speed are key parameters (AWEA, 2007).

\subsubsection{Noise impact}

Noise can generally be classified according to its two main sources: aerodynamic and mechanical. Aerodynamic noise is produced when the turbine blades interact with eddies caused by atmospheric turbulence. Mechanical noise is generated by the rotor machinery such as the gearbox and generator. Noise could be reduced by better designed turbine blade geometry and by selection of proper operating conditions (Cavallaro and Ciraolo, 2005).

\subsection{Social considerations}

Social factors that affect the selection of a site include public acceptance, distance from residential area and alternative land use options of candidate wind farm site. Some 
regulatory procedures may set restrictions or incentives to apply wind farm projects. Public acceptance is vital for the application of that kind of projects. Public may oppose projects because of possible environmental or social effects. Distance from residential area gain importance not to interfere with social life during wind farm construction or operation.

\subsubsection{Regulatory boundaries}

There may be some national or international level regulation related with the construction and operation of wind farms. These regulations must be explored before evaluating the socio-political position of a wind farm project. Most of them probably change from region to region. For example this distance is given as $300 \mathrm{~m}$ in the study of Clarke (1991), and 500m in the study of Yue and Wang (2006). Some nations encourage use of renewable energy resource and develop special regulations for the renewable energy generation plants. On the other hand, there could be some restrictions related with the construction and operation of energy generating plant. For example, in many of the national legislations, there is a distance where wind turbines are located from bird flyways.

\subsubsection{Public acceptance}

Public is the most vital component of a region and their opposition to issues can lead to abolish proposed projects. Support of public for wind energy generation is expected to be high in general but proposed wind farms have often been met with strong local opposition. In the study of D.van der Horst and Toke (2010), it is stated that nearby residents are more likely to become involved in decision making. It is recommended to inform public before deciding to construct a wind farm in a region especially where alternative land use is more beneficial to public than wind farm sitting (AEWA, 2007).

\subsubsection{Land use}

Land use affects the decision of wind farm siting from two points of view. Firstly, there are some cases where no wind farms can be built although sufficient wind speed was detected. These cases are mainly related with land use or condition. Land related constraints are:

- forest area

- wetlands

- land of high productivity

- archaeological sites

- aviation zones

- military zones

Alternative land uses of site where wind farm to be constructed affect the decision of wind farm site. More beneficial land uses for public especially such as agriculture, potential of being residential or industrial area, tourism cause oppositions and more detailed analysis of decision.

\subsubsection{Distance from the residential area}

Wind turbines are giant machines that can be over $120 \mathrm{~m}$ tall and have blades that sweep up to $6000 \mathrm{~m}^{2}$ in area. Because of their big size, these machines have the potential to disturb visual scene. Besides, noise and vibration stemming from the wind turbines may cause residents to suffer from sleep disturbance, headaches, visual blurring. Those types of complaints can be avoided if the wind turbines are sited a considerable distance from the 
residential area. In addition, construction of wind farm can disturb social life in the region for a long time due to large trucks carrying blades and debris from site excavation and construction machines.

\section{FAHP Chang's model}

AHP is a multi-criteria decision making tool which provides to structure complex problems in a hierarchic manner, as a result it simplifies evaluating all of the criteria which are relevant with the decision that must be given (Saaty, 1980). All of the alternatives are compared pairwise based on each criterion by using a preference scale and a priority list of alternatives is achieved for each criterion (Taha, 2003). Most widely used preference scale is 1-9 scale which lies between "equal importance" to "extreme importance". Fuzzy AHP enables the decision analyst to give more realistic scores for alternatives for the cases in which there are lots of uncertainties. For different perspectives, a variety of modified versions of fuzzy AHP can be used. Chang's model of extent analysis (1992) is one of them which depends on degree of possibility of the each criterion. Triangular fuzzy numbers $(l$, $\mathrm{m}, \mathrm{u}$ ) are used in order to develop pair wise comparison scale and a pair wise comparison matrix is constructed for each level in the hierarchy. Then, subtotals of each row in the matrix are calculated in order to have a new set. Overall triangular fuzzy values $\left(l_{i}, m_{i}, u_{i}\right)$ for criterion $\mathrm{M}_{\mathrm{i}}$ is obtained by calculating $\mathrm{l}_{\mathrm{i}} / \Sigma \mathrm{l}_{\mathrm{i}}, \mathrm{m}_{\mathrm{i}} / \sum \mathrm{m}_{\mathrm{i}}, \mathrm{u}_{\mathrm{i}} / \Sigma \mathrm{u}_{\mathrm{i}},(\mathrm{i}=1,2, \ldots, n)$. Membership functions, which mean corresponding weights of alternatives in the related matrix, are calculated for each criterion by using these values. They are normalized and final importance weights of each criterion are obtained.

To apply the process depending on this hierarchy, according to the method of Chang's (1992) extent analysis, each criterion is taken and extent analysis for each criterion, $\mathrm{g}_{\mathrm{i}}$; is performed on, respectively. Therefore, $\mathrm{m}$ extent analysis values for each criterion can be obtained by using following equation 1 (Kahraman, et al., 2004):

$$
S_{i}=\sum_{j=1}^{m} M_{g_{i}}^{j} \otimes\left[\left.\sum_{i=1}^{n} \sum_{j=1}^{m} M_{j, j}^{j}\right|^{-1}\right.
$$

Where $g_{i}$ is the goal set $(i=1,2,3,4,5, \ldots . ., n)$ and all the $g_{i} M(j=1,2,3,4,5, \ldots . . m)$ are Triangular Fuzzy Numbers (TFNs). The steps of Chang's analysis can be given as in the following:

Step 1. The fuzzy synthetic extent value $\left(S_{\mathrm{i}}\right)$ with respect to the $i_{\text {th }}$ criterion is defined as equation 1.

Step 2. The degree of possibility of $\mathrm{M}_{2}=\left(\mathrm{l}_{2}, \mathrm{~m}_{2}, \mathrm{u}_{2}\right)>\mathrm{M}_{1}=\left(\mathrm{l}_{1}, \mathrm{~m}_{1}, \mathrm{u}_{1}\right)$ is defined as equation 2 :

$$
V\left(M_{2} \geq M_{1}\right)=\sup _{y \geq x}\left[\min \left(\mu_{M_{1}}(x), \mu_{M_{2}}(y)\right)\right]
$$

Step 3. $x$ and $y$ are the values on the axis of membership function of each criterion. This expression can be equivalently written as given in equation 3 below:

$$
V\left(M_{2} \geq M_{1}\right)= \begin{cases}1, & \text { if } m_{2} \geq m_{1}, \\ 0, & \text { if } l_{1} \geq u_{2}, \\ \frac{l_{1}-u_{2}}{\left(m_{2}-u_{2}\right)-\left(m_{1}-l_{1}\right)} & \text { otherwise }\end{cases}
$$




\section{Case study: Turkey}

Turkey, with a fast growing economy and population, has been experiencing substantial demand growth in all segments of the energy sector. This demand is mainly met by importing of energy primarily oil and natural gas. With the enforcement of the Electricity Market Law in 2001, the Natural Gas Market Law in 2001, the Oil Market Law in 2005, Liquefied Petroleum Gases Law in 2005 and the Market Law in 2005, significant steps were taken for the creation of a competitive and functional market in Turkish energy sector. Liberalization which aims to create a competitive environment and to enhance the investment is now being applied under the supervision of the Energy Market Regulatory Authority (EMRA).

In order to reduce the energy import dependency, utilization of renewable energy sources has been supported since 1984. Diversifying the country's natural resource supply and increasing the share of renewable energy sources are at the top of the list of the Turkish Ministry of Energy and Natural Resources' four year strategic plan (2010-2014) (ETKB, 2010). With this aim, first in 2005, The Law on The Utilization of Renewable Energy Resources For The Purpose of Generating Electrical Energy was enacted. By the end of 2010, an amendment to this law (Law number 6094) was done. The main reason of amendment is the reconstruction of the supporting mechanisms (feed-in tariff and purchase guarantee) to increase the investments. With the supporting mechanisms and the developments in the renewable energy technologies, Prime Ministry Undersecretariat of State Planning Organization put a target of increasing the share of renewable resources in electricity generation up to at least $30 \%$ by 2023 (DPT, 2009).

To reach the target, maximum use of renewable resources must be ensured. Among the renewable energy resources, wind has been the most popular for the investors. Turkey has a very large potential for wind power. Turkey has a minimum wind energy potential of 5.000 MW in regions with annual wind speed of $8.5 \mathrm{~m} / \mathrm{s}$ and higher, and $48.000 \mathrm{MW}$ with wind speed higher than $7.0 \mathrm{~m} / \mathrm{s}$ (REPA, 2007). However, not all of the sites having high wind velocity are suitable for wind farm construction due to several reasons explained in the study. Therefore, it is necessary to evaluate potential sites for wind farm construction by considering using a holistic approach such as proposed in this study.

\subsection{Scenario: Alternative sites for wind farm in Turkey}

According to the data published on the webpage of the Ministry of Energy and Natural Resources (ETKB), Turkey's installed power for wind energy reached the level of $802.8 \mathrm{MW}$ as of the end of 2009. Upon taking effect of the Renewable Energy Law, licenses were granted to 93 new wind projects which deliver a total installed power of $3.363 \mathrm{MW}$.

To decrease the time and cost of any feasibility analysis, General Directorate of Electrical Power Resources Survey and Development Administration (EIE) developed a wind map which provides three different numerical atmosphere analysis model combined with meteorological data (Figure 2). For potential wind farm locations, map is integrated to a geographical information system model. This map includes topography, rivers, lakes, civilization areas, special forest terrain, highways, railroads, harbors, airports, energy transmission lines and transformer stations.

REPA also has a map where the wind farms cannot be built for various reasons such as cities, density of population, archeological value, historic value and many more. In Figure 3, the black area shows the place where no wind farms can be built. 

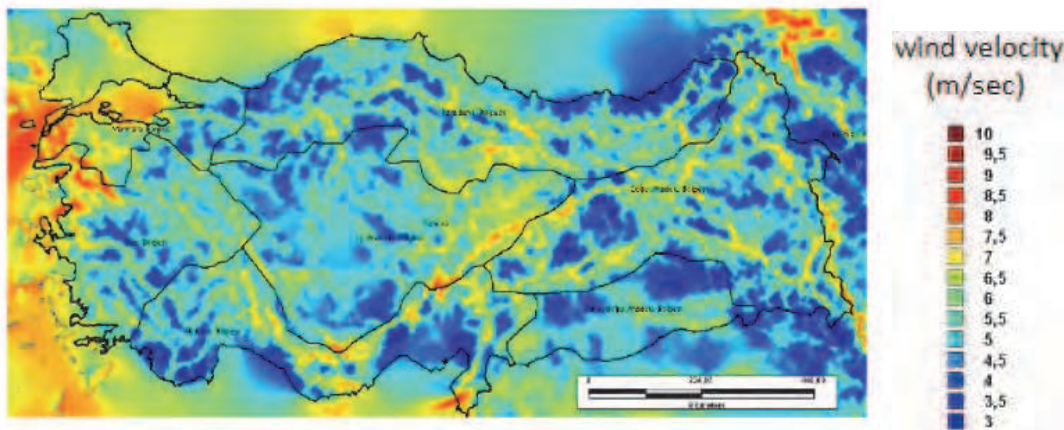

Fig. 2. Average yearly wind velocity distribution of $50 \mathrm{~m}$ height (REPA, 2007).

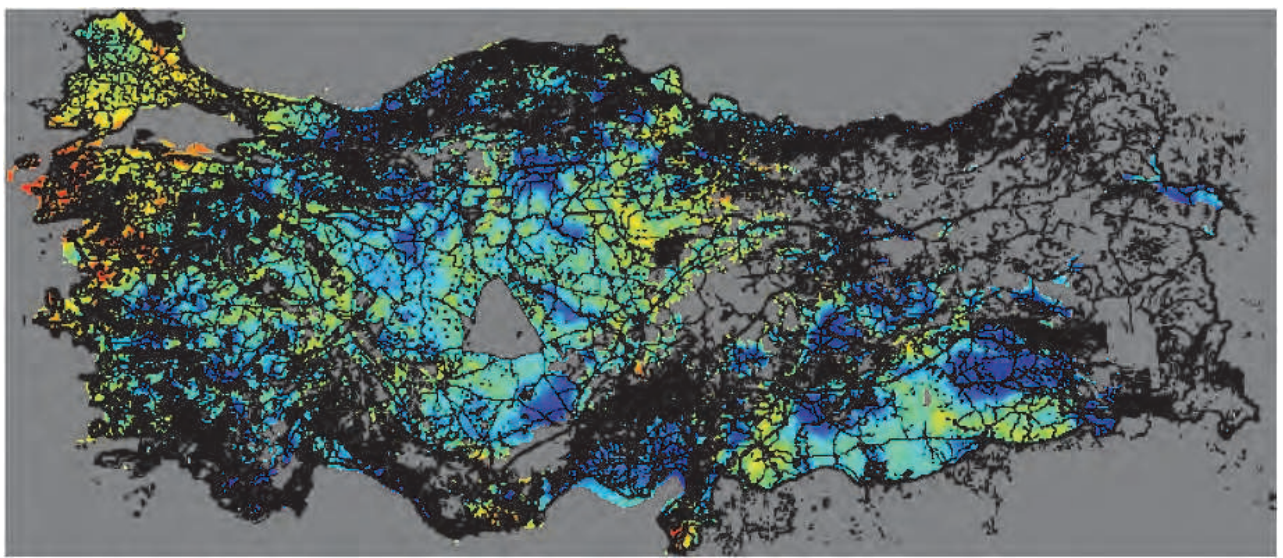

Fig. 3. REPA map of unusuable area for wind farm siting (Edremitlioğlu et al., 2007)

Based on the REPA map, it may be concluded that the regions of north Aegean, Marmara and East Mediterranean have high wind energy potential. Annual average wind speed and wind density values for the regions of Turkey were given in Table 1 in order to compare with Figure 2 where wind velocity distribution is given for each point in Turkey.

\begin{tabular}{ccc}
\hline Region & $\begin{array}{c}\text { Annual average } \\
\text { wind speed }(\mathrm{m} / \mathrm{s})\end{array}$ & $\begin{array}{c}\text { Annual average } \\
\text { wind density }\left(\mathrm{W} / \mathrm{m}^{2}\right)\end{array}$ \\
\hline Marmara & 3.3 & 51.9 \\
Southeast Anatolia & 2.7 & 29.3 \\
Aegean & 2.6 & 23.5 \\
Mediterranean & 2.5 & 21.4 \\
Black Sea & 2.4 & 21.3 \\
Central Anatolia & 2.5 & 20.1 \\
East Anatolia & 2.1 & 13.2 \\
Turkey Average & 2.5 & 24.0 \\
\hline
\end{tabular}

Table 1. Wind potential of various regions in Turkey (Erdoğdu, 2009). 
It is clear that wind distribution map is more meaningful than annual average wind speed data for regions. As a result, wind velocity distribution map should be used in order to determine alternative sites for wind farm construction, and to make decision analysis for selecting the most suitable location among the alternative sites.

It is planned to construct a wind farm that has a capacity of $750 \mathrm{MW}$ according to the strategic plan of ETKB. Based on the Figure 2 and Figure 3, Karaman (Sertavul), İzmir (Bergama), İstanbul (Tuzla) and Muğla (Gökova) are selected as candidate sites for wind farm construction due to their potential wind speed and not being an unusable area. Necessary information about alternative sites were given that would be useful while assessing alternative sites for wind farm construction. However, they must be assessed from much more points of view than wind speed; necessary data must be gathered in order to make evaluation between alternatives by using proposed hierarchy. For this cases study, economical factors of electricity market and incentives and social factors of regulatory boundaries were not considered, since electricity that is produced by each alternative site will be delivered to the central grid system of Turkey. Therefore, electricity market is the same for all of the alternatives. Also, all of them share the same restrictions or the opportunities from the incentives and regulatory boundaries point of view; there is no change region to region for incentives and regulations.

\subsubsection{Properties of alternative sites for wind farm construction}

Karaman (Sertavul) is located in Central Anatolia of Turkey and have average wind speed of around 7-7.5 cm/s (Figure 1) which has the potential of wind power and above the average speed of Turkey. However, land topography and geology is not so suitable to construct wind farm. It is relatively a steeper land and there are high mountains having 2000 $\mathrm{m}$ average height round the site. On the other hand, selected area is far away from surface and ground water sources. Although, Karaman has a rich wild life \& endangered species; location of candidate wind farm site does not endanger the life of a substantial number of species. Population density is high in the central of city, as a result noise and visual impact may not be considered as an important environmental issue of wind farm due to its being very far away from central of city. In addition, location does not have a beneficial alternative land use such as being an agricultural, touristic or strategic area (URL-1). However, the grid is not so close to wind farm area due to being a relatively isolated area (ETKB, 2010).

Istanbul is located in the south west of Turkey in Marmara Region. Tuzla is located in the Anatolian (Asia) region of the city. Tuzla has an average wind speed of 7-7.5 m/s (Figure 1). Relatively steeper lands and solid rocks are dominant geologic formation in the region. However, sources of groundwater and foundation are spread in the region and precautions have to be taken about the stability of constructions. Tuzla has high population density and boundaries of residential area are extensive. There are lots of industrial estates and zones due to its being close to important transportation means. Visual and noise impact of wind farm become important as a result of the topography and existing layout of the region (residential areas and industries). On the other hand, the region is not rich of wild life and endangered species (URL-2). Alternative land uses are critical for Tuzla, because region is one of the most widely preferred areas for industrial zones and depending on this the demand for residential area close to these zones is high. Tuzla is close to grid and transmission lines (ETKB, 2010).

İzmir (Bergama) is located in the west of Turkey in Aegean Region. There are valleys, mountains and surface water sources in the region. Population density is about tenfold 
higher in central of the region than in rural areas. However, there are very steep lands, protected areas due to archaeological heritages in the region and primary seismic zones; selected wind farm site is relatively a plain area, the potential of earthquake is not so high and it is far away from protected areas. There are not wild life and endangered species that must be protected in the site. There is another wind farm site in the region which will provide compatibility of proposed wind farm project with the view of the region. In addition, area is far away from the residential area and noise and aesthetic possibly will not disturb residents of the region (Bergama, 2009). Although proposed site has not any beneficial alternative, it may be attractive for touristic plants due to its being relatively close to touristic areas. Wind speed is about $8-8.5 \mathrm{~m} / \mathrm{s}$ (Figure 1) in the region and there is a high potential of energy production. Moreover, there is a ready grid to transmit energy to central system very close to site (ETKB, 2010).

Muğla is located in the south west of Turkey in Aegean Region. Wind speed of the region is around $6 \mathrm{~m} / \mathrm{s}$ (Figure 1) and it is the smallest among the other alternative sites. However, land topography of Muğla is very plain and formation of earth is relatively strong enough for wind farm sitting. Population density of Muğla varies seasonally. Population is heavily crowded in the seaside in summer and low in winter. Wild life and endangered species is a very important environmental aspect for Muğla (URL-3). Noise and visual impact could be neglected, when the existing residential layout which is far away from the site and facilities such as thermic central near the site are taken into consideration. Alternative land use of Bergama is also valid for Muğla, however Muğla has much more problematic facilities in the site which decreases the possibility of alternative land use in the site. There is a grid close to site and structure is compatible with the planned wind farm project (ETKB, 2010).

\subsubsection{Application of proposed hierarchy to case study}

Four alternative sites for wind farm sitting are evaluated based on the necessary information given about sites and scenario by using the methodology explained. All of the factors in the same level were compared with each other by using the scale (Table 2) formed in order to make pair-wise comparison. Comparisons are made based on the priority of the factor relative to the other factor being compared.

Evaluation is made by the authors of the study who have background of environmental, chemistry, energy systems and industrial engineering and business administration. Therefore, expert opinions on technical, economic, environmental and social factors could be provided. For further applications, contributions of experts on earth science and social science and representatives of non-governmental organizations are advised in order to have an extended analysis of decision making on real-time issues.

An individual score must be given for each factor comparison by discussing and sharing the knowledge about factors in order to have a holistic evaluation. Based on the scores given for comparison, synthetic numbers were formed by using equation 1 and minimum ones were chosen by using equation 2. Priority numbers of factors were derived from normalized synthetic results (Table 3). Secondly, alternatives are compared based on each sub factor in order to have priority numbers of alternatives which are specific to factor considered. These priority numbers were obtained by following the same procedure explained above. For the overall results, in which priority number for the alternatives are obtained, priority numbers of the alternatives for each factor is aggregated after multiplying it with the priority number of the related factor. 


\begin{tabular}{cc}
\hline Intensity of Importance & Triangle Fuzzy Number \\
\hline Very low & $(1 / 9,1 / 9,1 / 7)$ \\
Low & $(1 / 9,1 / 7,1 / 5)$ \\
Moderately Low & $(1 / 7,1 / 5,1 / 3)$ \\
Moderate Low & $(1 / 5,1 / 3,1)$ \\
Just equal & $(1,1,1)$ \\
Moderate High & $(1,3,5)$ \\
Moderately High & $(3,5,7)$ \\
High & $(5,7,9)$ \\
Very High & $(7,9,9)$ \\
\hline
\end{tabular}

Table 2. Triangle Fuzzy Number for Intensity of Importance

\subsubsection{Results and discussion}

First group of results, which are related with the priority of factors for site selection, are more general than others. They have been scored by considering general aspects related with the aim. According to the results given in Table 3, among the factors effecting the wind farm site selection, environmental (0.33) and social ones (0.29) are mostly effective.

Technical factors are relatively close to social factors; however economic factors have the least priority from site selection point of view. All of the production and service facilities must ensure the sustainability of life and environment. Selection of a project that costs very low in spite of harming environment and society should not be allowed. Technical and economic feasibility must be optimized based on the restrictions of environmental and social sustainability. Damage on wild life and endangered species and electromagnetic interference have the same and highest priority (0.32) for selection due to their being irreparable injuries. Noise and visual impact is relatively tolerable $(0.19$ and 0.18 , respectively) than other environmental effects, because there are precautions that can be taken during or after wind farm construction.

Land use is the most important social factor (0.45), since there is a need for big lands in order to construct wind farm and these lands may be used for much more beneficial purposes such as agriculture, tourism or strategic. Distance to residential area must be considered seriously due to its effect on society both during and after the construction. If environmental and other social factors are sustained, public acceptance will also be provided mostly. Therefore, its direct effect on the site selection become as least effective social factor.

Among technical sub factors, wind speed and grid structure and distance have the highest priority $(0.31)$ due to their effects on energy efficiency, capacity factor and being ever ready. On the other hand, land topography and geology (0.25) determines the stability of the wind turbines and technical feasibility of their construction. Also, turbine size does not have a direct contribution to technical feasibility (0.13), required turbine size for the planned capacity would be restricted with alternative suppliers of turbine generators and available land resources.

Capital cost is the most distinguishing factor (0.46), because it is known that capital cost is the biggest contributor of total cost due to high construction and turbine costs. However, need of large area makes land cost as important as capital cost and varies region to region dramatically. Although operational \& management costs varies with region, its contribution 
to total cost is mostly very small which include the expenses of the employees and maintenance of equipment in general.

\begin{tabular}{cccc}
\hline Factors & $\begin{array}{c}\text { S number } \\
\text { Eq } 2\end{array}$ & $\begin{array}{c}\operatorname{minV}(\mathrm{Si}>\mathrm{Sj}) \\
\mathrm{Eq} 3\end{array}$ & $\begin{array}{c}\text { Priority } \\
\text { normalization }\end{array}$ \\
\hline Technical Factors & {$[\mathbf{0 . 0 6 , 0 . 1 9 , 0 . 7 1 ]}$} & $\mathbf{0 . 7 3}$ & $\mathbf{0 . 2 4}$ \\
Wind Speed & {$[0.19,0.5,1.33]$} & 1 & 0.31 \\
Land Topography \& Geology & {$[0.05,0.16,0.49]$} & 0.8 & 0.25 \\
Grid Structure \& Distance & {$[0.08,0.26,0.80]$} & 1 & 0.31 \\
Turbine Size & {$[0.04,0.07,0.22]$} & 0.43 & 0.13 \\
Economic Factors & {$[\mathbf{0 . 0 4}, \mathbf{0 . 0 8 , 0 . 3 6 ]}$} & $\mathbf{0 . 4 4}$ & $\mathbf{0 . 1 4}$ \\
Capital Cost & {$[0.15,0.54,1.67]$} & 1 & 0.46 \\
Land Cost & {$[0.11,0.34,1.06]$} & 1 & 0.46 \\
O\&M Cost & {$[0.07,0.12,0.23]$} & 0.16 & 0.07 \\
Environmental Factors & {$[\mathbf{0 . 1}, \mathbf{0 . 4 2}, \mathbf{1 . 4 3}]$} & $\mathbf{1}$ & $\mathbf{0 . 3 3}$ \\
Visual Impact & {$[0.05,0.16,0.49]$} & 0.56 & 0.18 \\
Wild Life \& Endangered & {$[0.14,0.43,1.19]$} & 1 & 0.32 \\
Species & {$[0.06,0.16,0.47]$} & 1 & 0.32 \\
Electromagnetic Interference & {$[0.06,0.17,0.53]$} & 0.6 & 0.19 \\
Noise Impact & {$[\mathbf{0 . 0 8 , 0 . 3 7 , 1 . 0 7 ]}$} & $\mathbf{0 . 9}$ & $\mathbf{0 . 2 9}$ \\
Social Factors & {$[0.07,0.13,0.45]$} & 0.42 & 0.19 \\
Public Acceptance & {$[0.15,0.54,1.67]$} & 1 & 0.45 \\
Land Use & {$[0.11,0.34,1.06]$} & 0.81 & 0.36 \\
\hline Distance to Residential Area & & &
\end{tabular}

Table 3. Calculating the priority numbers by Chang Model

Detailed results of calculations for each alternative are shown in Table 4. Priority numbers of the alternatives for each main factor is shown in Figure 4. From environmental point of view, Karaman and İzmir has the same and highest priority as a candidate for wind farm sitting. Izmir is one of the preferable regions due to its having very small number of wild life and endangered species and being relatively isolated from the electromagnetic interference potential. Moreover, location of the selected site has a low potential of visual and noise impact. Although wild life and endangered species are relatively rich in Karaman, it is also the most preferred site based on environmental factors due to its being isolated from residential area which leads to low noise and visual impact.

Although İstanbul is the most preferred site because of being poor in number of wild life and endangered species, it is the least preferred site from other environmental points of view due to high number of industrial zones and its being close to residential area. However, Muğla is moderately preferred based on visual, noise impact and electromagnetic interference, richness of wild life and endangered species near the candidate location make Muğla one of the two least favourable site based on environmental issues. 


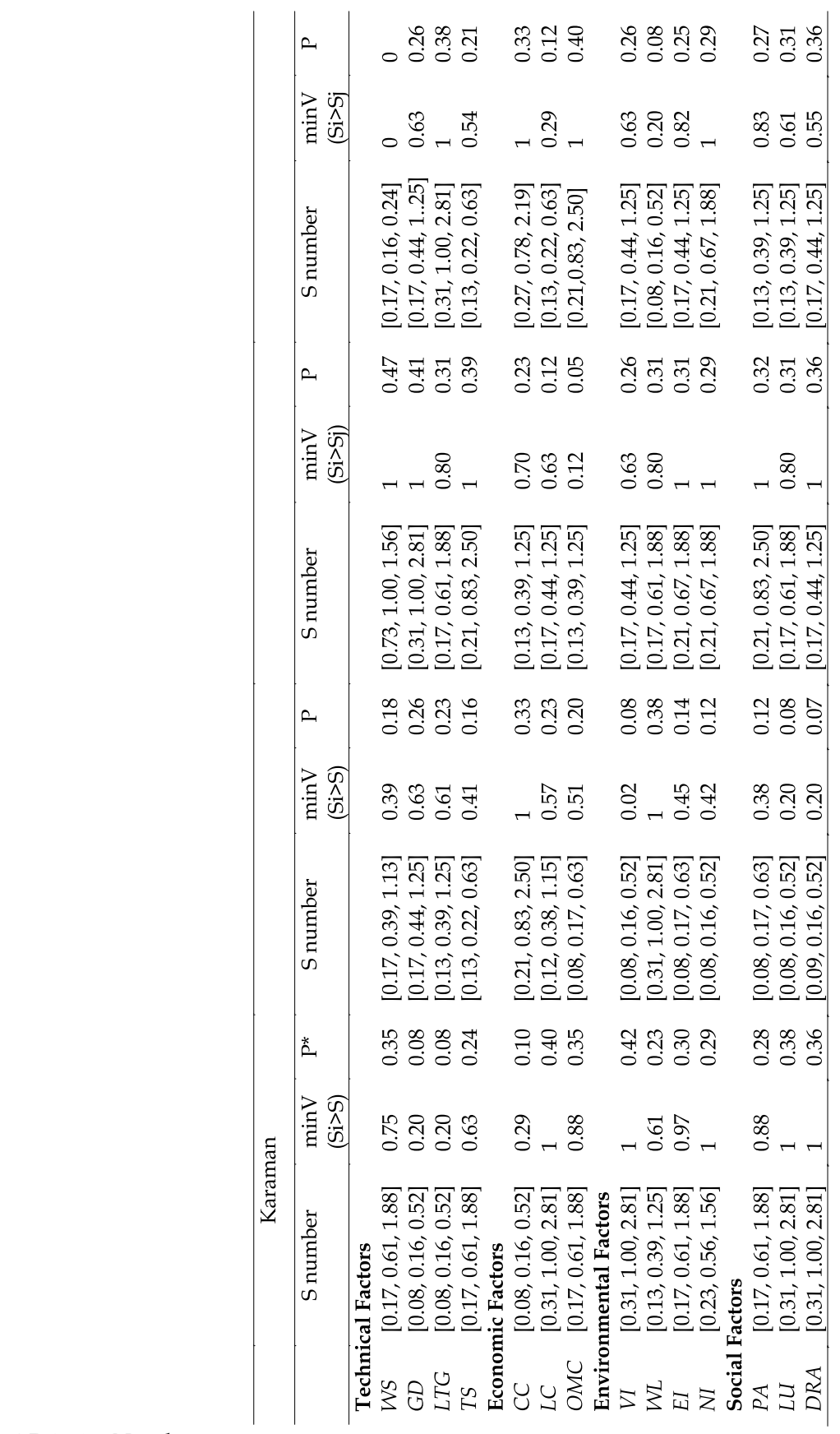

* Priority Number

Table 4. Comparison results of sub-factors for Chang' s Analysis 


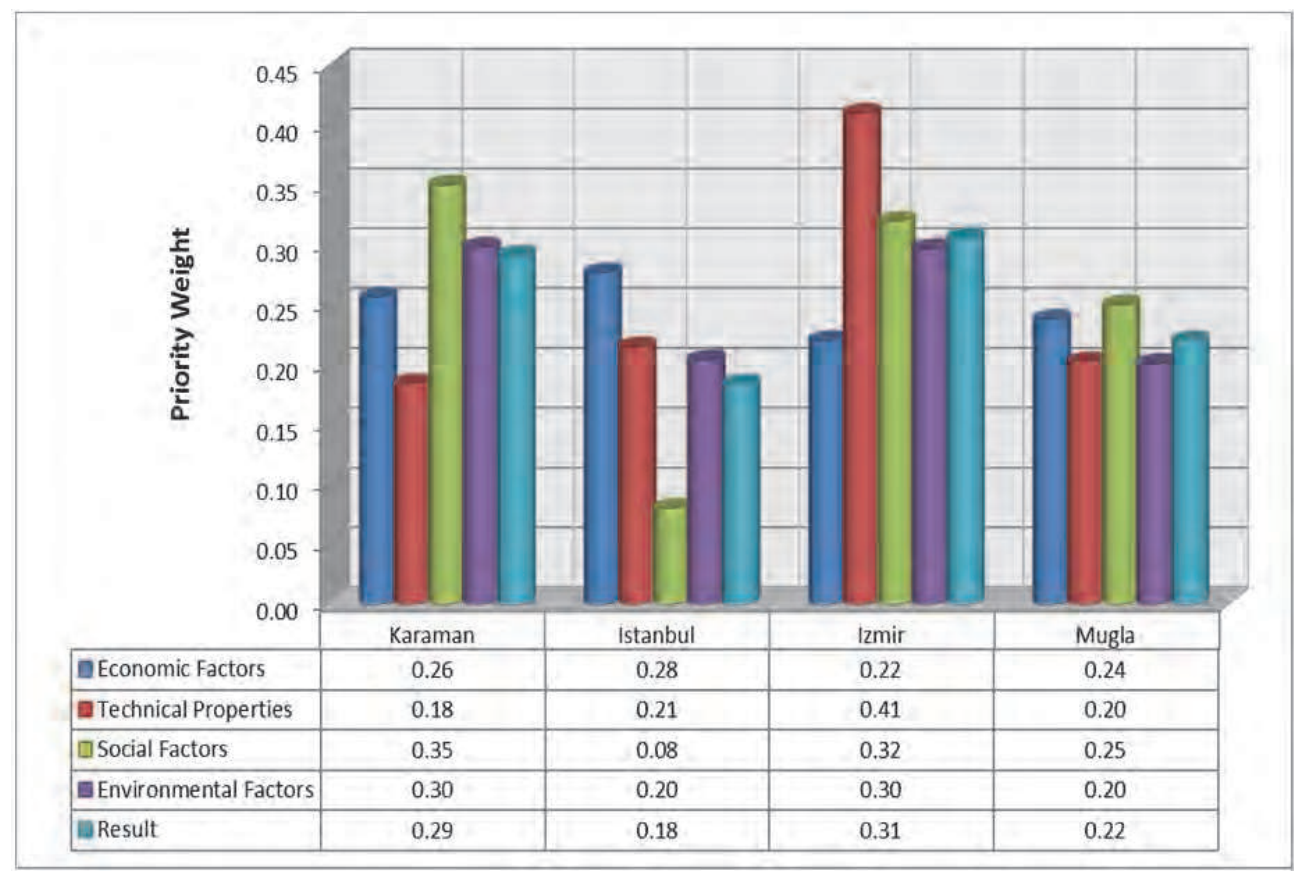

Fig. 4. Priority weights of each factor for the alternatives

Social factors lead to selection of Karaman as most appropriate site (0.35) for wind farm project. Expectation of society to become a developed city results in the acceptance of such an energy production project which is already does not cause serious environmental problems. In addition, there is no alternative beneficial use for the land and residential area is far away from the site. Same reasons are valid for Izmir which has about the same priority number (0.32) with Karaman.

For Muğla, public acceptance and alternative land uses are critical. Muğla has a thermal power plant and against to the further projects around the region. Istanbul is certainly the least preferred site due to social factors. High potential of being an industrial zone bring the alternative land use in the foreground and public acceptance become restricted due to both alternative land use and environmental impacts. Also, being a dense residential area is a big disadvantage that cannot be tolerable in any way.

İzmir is a distinguished alternative from technical points of view. Average wind speed is higher than the other sites and there is a close grid in the site serving for another wind farm. Therefore, its turbine size is small as possible as due to high wind speed and there is no restriction about the suppliers. Land topography and geology is relatively make it hard to construct a wind farm, however it can be overcome relatively easier due to existing experiences about wind farm construction in the site. 
Istanbul, Muğla and Karaman have almost the same priority number for technical factors which are $0.21,0.20$ and 0.18 , respectively. Although average wind speed is relatively high in Karaman and there is no debate about turbine size due to large available area, long distance between wind farm and grid in Karaman and construction problems due to land topography and geology cause Karaman to be in the last order based on technological factors. Muğla also has low priority due to low wind speed and high turbine size which need large area. Low wind speed and especially the availability of wind reduce the electability of Istanbul.

Economic priorities of the sites are very close to each other. Istanbul is the most advantageous city from economic point of view due to low capital cost need which has the highest share in the total cost. There are lots of construction firms in Istanbul and land topography and geology is not so hard in Istanbul for construction. Most of the construction equipment is readily available and the need of construction of extra roads, equipment storage areas etc. are minimum owing to existing infrastructure.

Muğla also have the same advantageous for capital cost. Land cost is lowest in Karaman and highest in Muğla where public acceptance is doubt and alternative use of the site is possible. Muğla and Karaman have the lowest operational and maintenance cost due to cheap work force.

When all of the priority numbers of each alternative are aggregated, results shown in Figure 5 are achieved. Izmir is the most preferred site for wind farm construction and Karaman has around the same priority number with the Izmir. They have almost the same characteristics for environmental, social and economic factors, however wind speed of Karaman is lower than Izmir and grid distance is much closer in Izmir than it is in Karaman. As priorities of technological factors are lower than priorities of environmental and social factors; there is not a big difference between Izmir and Karaman to construct wind farm.

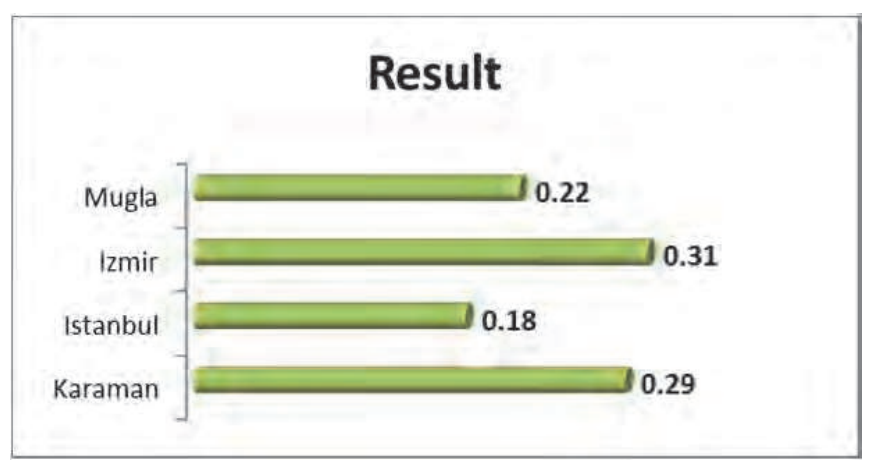

Fig. 5. Priority weights of alternatives

Methodology provides the decision maker to make extended analysis of results based on the priorities of alternatives specific to factors. Decision maker can determine a critical factor to give decision and select the site by considering the priority of the site based on this factor. 
For example, Karaman can be selected due to its higher priority for economic and social factors rather than Izmir.

Moreover, Karaman and Izmir can be analysed in detail which is not possible for more than two alternatives from economic and social point of view. Muğla and Istanbul, which has low priority for environmental, social and technical point of view, is certainly must be eliminated according to the results.

\section{Conclusion}

Wind energy has become widely used in recent years in order to increase the usage of renewable energy sources instead of fossil fuels or nuclear energy. Therefore, wind farm site selection is a vital issue that must be analysed deeply in order to have efficient wind power generation from technical and economic point of view without damaging environment and society. However, there are lots of factors that make contribution to selection of wind farm site and they must be organized with a systematic hierarchy in order to make decision with a holistic approach. Also, uncertainties could appear about the effects of these factors. Due to these reasons, Chang's extent analysis of FAHP is a proper method for decision making on wind farm site.

This methodology provides three groups of the result which are priority numbers of the factors based on the wind farm site selection, priority numbers of the candidate sites specific to each factor and aggregated priority number of each alternative based on all of the factors affecting wind farm selection. Therefore, methodology offers a number of advantages for analysing the wind farm site selection deeply.

First of all, it enables the user to identify the source of the problem related with the inappropriateness of the site owing to priority numbers of the site specific to each factor. Secondly, priority numbers of the factors based on the wind farm site selection give the opportunity of reflecting the importance weight of the factor on site selection in quantitative assessments. Overall results provide to distinguish the alternatives from each other and reduce the number of alternatives especially for further detailed decision analysis.

Technical, economic, environmental and social factors are the main factors contributing site selection problem. Environmental and social factors are distinctive ones that distinguish technically and economically feasible sites. Different alternatives could be the most suitable area for wind farm according to different factors. Composing of these factors gives the most suitable site according to combined effect of factors.

\section{References}

American Wind Energy Association (AWEA). (2007). 10 Steps in building a wind farm. 17.02.2011, Avaliable from http://www.awea.org/pubs/factsheets.htm

Baban, S. \& Parry, T. (2001). Developing and applying a GIS-assisted approach to locating wind farms in the UK, Renewable Energy, Vol. 24, pp. 59-71, ISSN 0960-1481

Bergama Municipality, (2009). 2010-2014 Strategic Plan. 13.01.2011 Avaliable from http://www.bergama.bel.tr/Dokumanlar/2010-2014stratejikplan.pdf 
Bright, J.; Langston, R.; Bullman, R.; Evans, R.; Gardner, S. \& Pearce-Higgins, J. (2008). Map of bird sensitivities to wind farms in Scotland: A tool to aid planning and conservation. Biological Conservation, Vol. 141, pp. 2342-2356, ISSN 0006-3207

Brower, M. (1992). Cool energy: Renewable solutions to environmental problems, MIT Press, Cambridge, ISBN 0262023490.

Cavallaro, F. \& Ciraolo, L. (2005). A multicriteria approach to evaluate wind energy plants on an Italian island, Energy Policy, Vol. 33(2), pp. 35-44, ISSN 03014215

Chang, D.Y., 1992. Extent analysis and synthetic decision. Optimization Techniques and Applications, 1. World Scientific, Singapore, Vol. 1, p. 352.

Clark, J. G. (1991). The political economy of world energy: A twentieth-century perspective, Chapel Hill, North Carolina, USA, ISBN 0807819441

Edremitlioğlu, H. H.; Toydemir, C. K. \& Başkan, O. (2007). Economical, Environmental Outcomes of Wind Energy Production in Turkey. Qualifying Project for the degree of Bachelor of Science

Erdoğdu, E. (2009). On the wind energy in Turkey. Renewable and Sustainable Energy Reviews, Vol. 13, pp. 1361-1371, ISSN 1364-0321

European Wind Energy Association (EWEA). (2009). Wind Energy-The Facts, ISBN 9781844077106, Earthscan, UK

Herbert G. M. J.; Iniyan S.; Sreevalsan, E. \& Rajapandian S. (2007). A review of wind energy technologies. Renewable and Sustainable Energy Reviews, Vol. 11, pp. 1117-45, ISSN 1364-0321

Kahraman, C., Cebeci, U. \& Ruan, D. (2004). Multi-attribute comparison of catering service companies using fuzzy AHP: the case of Turkey, International Journal of Production Economics, Vol. 87, pp. 171-184, ISSN 0925-5273

Kaya, T. \& Kahraman, C. (2010). Multicriteria renewable energy planning using an integrated fuzzy VIKOR \& AHP methodology: The case of Istanbul, Energy, Vol. 35, pp. 2517-2527, ISSN 0360-5442

Kikuchi, R. (2008). Adverse impacts of wind power generation on collision behavior of birds and anti-predator behavior of squirrels. Journal for Nature Conservation, Vol. 16, pp. 44-55, ISSN: 1617-1381

Kusiak, A. \& Song, Z. (2010). Design of wind farm layout for maximum wind energy capture. Renewable Energy, Vol. 35, pp. 685-694, ISSN 0960-1481

Lee, A. H. I.; Chen, H. H. \& Kang, H. Y. (2009). Multi-criteria decision making on strategic selection of wind farms, Renewable Energy, Vol. 34, pp. 120-126, ISSN 0960-1481.

Manwell, J.F.; McGowan, J.G. \& Rogers, A.L. (2002). Wind Energy Explained: Theory, Design and Application, John Wiley\&Sons, ISBN 0-471-49972-2, UK

Munday, M.; Bristowb, G. \& Cowell, G. (2011). Wind farms in rural areas: How far do community benefits from wind farms represent a local economic development opportunity?, Journal of Rural Studies, Vol. 27, pp. 1-12, ISSN 07430167 
Ozerdem, B.; Ozer, S. \& Tosun, M. (2006). Feasibility study of wind farms: A case study for Izmir, Turkey. Journal of Wind Engineering and Industrial Aerodynamics, Vol. 94, pp. 725-743, ISSN 0167-6105

Republic of Turkey- Prime Ministry Under secretariat of State Planning Organization (DPT). (2009). Electricity Energy Market and Supply Security Strategy Paper, 13.11.2010. Avaliable from http://www.enerji.gov.tr/yayinlar_raporlar_EN/ Arz_Guvenligi_Strateji_Belgesi_EN.pdf

Saaty, T. L. (1980). The Analytical Hierarchy Process, Mc Graw Hill, New York.

Taha, H. A., (2003). Operations Research, Pearson Education Inc., Fayetteville, ISBN 0131429159

Tegou, L. I.; Polatidis, H. \& Haralambopoulos, D. A. (2010). Environmental management framework for wind farm siting: Methodology and case study. Journal of Environmental Management, Vol. 91, pp. 2134-2147, ISSN 03014797

The Republic of Turkey Ministry of Energy and Natural Resources (ETKB). (2010). Strategic Plan (2010-2014), 24.12.2010, Avaliable from

http://www.enerji.gov.tr/ yayinlar_raporlar_EN/ETKB_2010_2014_Stratejik_Plani_EN.pdf

Turkey Wind Energy Potential Atlas (REPA). (2007). 12.11.2010 Avaliable from $<$ http://repa.eie.gov.tr>

Twidell, J. \& Weir, T. (2006). Renewable Energy Resources. Taylor\&Francis, 2nd Edition, ISBN 978-0-419-25330-3, UK

Ucar, A. \& Balo, F. (2009). Evaluation of wind energy potential and electricity generation at six locations in Turkey. Applied Energy, Vol. 86, pp. 1864-1872, ISSN 0306-2619

UNDP, Serbia. (2010). Guidelines on the environmental impact assessment for wind farms. 05.12.2010 Avaliable from http://www.unece.org/env/eia/documents/ EIAguides/Serbia_EIA_windfarms_Jun10_en.pdf

Url-1 <http:/ / www.larende.com/default.asp?islem=k\&islemy=cografya\&islem $x=i b o>$

Url-2< http:/ / www.tuzla.gov.tr/default_B1.aspx?content=1>

Url-3 <http://www.mugla.gov.tr/>

Van der Horst, D. \& Toke, D. (2010). Exploring the landscape of wind farm developments; local area characteristics and planning process outcomes in rural England. Land Use Policy, Vol. 27, pp. 214-221, ISSN 0264-8377

Vanek, F. M. \& Albright, L. D. (2008). Energy Systems Engineering-Evaluation and Implementation. McGraw-Hill, ISBN 978-0-07-149593-6, USA.

Weisser, D. \& Garcia, R. S. (2005). Instantaneous wind energy penetration in isolated electricity grids: concepts and review, Renewable energy, Vol. 30 (8), pp. 1299-1308, ISSN 0960-1481

Welch, J. \& Venkateswaran, A. (2009). The Dual Sustainability of Wind Energy. Renewable and Sustainable Energy Reviews, Volume 13, Issue 5, pp. 1121-1126, ISSN 1364-0321 
Yue, C. D. \& Wang, S. S.; 2006. GIS-based evaluation of multifarious local renewable energy sources: a case study of the Chigu area of southwestern Taiwan, Energy Policy, Vol. 34, pp. 730-742, ISSN 0301-4215

Zhang, Z. X. (2007). China is moving away the pattern of "develop first and then treat the pollution. Energy Policy, Vol. 35, pp. 3547-3549, ISSN 0301-4215 


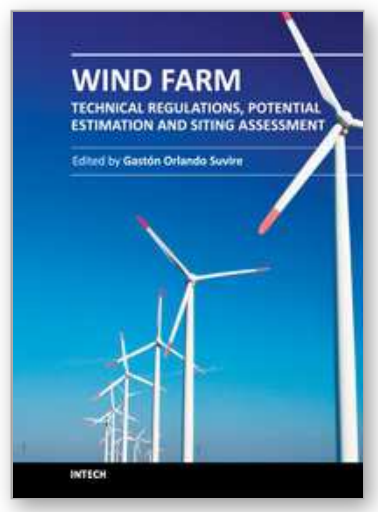

\section{Wind Farm - Technical Regulations, Potential Estimation and Siting Assessment}

Edited by Dr. Gast $\tilde{A}^{3} n$ Orlando Suvire

ISBN 978-953-307-483-2

Hard cover, 234 pages

Publisher InTech

Published online 14, June, 2011

Published in print edition June, 2011

The evolution of wind power generation is being produced with a very high growth rate at world level (around $30 \%$ ). This growth, together with the foreseeable installation of many wind farms in a near future, forces the utilities to evaluate diverse aspects of the integration of wind power generation in the power systems. This book addresses a wide variety of issues regarding the integration of wind farms in power systems. It contains 10 chapters divided into three parts. The first part outlines aspects related to technical regulations and costs of wind farms. In the second part, the potential estimation and the impact on the environment of wind energy project are presented. Finally, the third part covers issues of the siting assessment of wind farms.

\section{How to reference}

In order to correctly reference this scholarly work, feel free to copy and paste the following:

İlhan Talinli, Emel Topuz, Egemen Aydin and Sibel Kabakcı (2011). A Holistic Approach for Wind Farm Site Selection by Using FAHP, Wind Farm - Technical Regulations, Potential Estimation and Siting Assessment, Dr. Gast $\tilde{A}^{3} n$ Orlando Suvire (Ed.), ISBN: 978-953-307-483-2, InTech, Available from:

http://www.intechopen.com/books/wind-farm-technical-regulations-potential-estimation-and-sitingassessment/a-holistic-approach-for-wind-farm-site-selection-by-using-fahp

\section{INTECH}

open science | open minds

\section{InTech Europe}

University Campus STeP Ri

Slavka Krautzeka 83/A

51000 Rijeka, Croatia

Phone: +385 (51) 770447

Fax: +385 (51) 686166

www.intechopen.com

\section{InTech China}

Unit 405, Office Block, Hotel Equatorial Shanghai

No.65, Yan An Road (West), Shanghai, 200040, China

中国上海市延安西路65号上海国际贵都大饭店办公楼405单元

Phone: +86-21-62489820

Fax: $+86-21-62489821$ 
(C) 2011 The Author(s). Licensee IntechOpen. This chapter is distributed under the terms of the Creative Commons Attribution-NonCommercialShareAlike-3.0 License, which permits use, distribution and reproduction for non-commercial purposes, provided the original is properly cited and derivative works building on this content are distributed under the same license. 